\title{
Application of Myrcia splendens tannins in the composition of urea-formaldehyde adhesive for sustainable wood bonding
}

\author{
Aplicação dos taninos de Myrcia splendens na composição do adesivo urea-formaldeído para a \\ colagem sustentável de madeira
}

Aplicación de los taninos de Myrcia splendens en la composición del adhesivo de urea-formaldehído para el encolado sostenible de la madera

Received: 09/13/2021 | Reviewed: 09/19/2021 | Accept: 09/22/2021| Published: 09/24/2021

\author{
Dianessa Danielli \\ ORCID: https://orcid.org/0000-0001-8328-5985 \\ Federal University of Lavras, Brazil \\ E-mail: dianessa_danielli@hotmail.com \\ Marina Rates Pires \\ ORCID: https://orcid.org/0000-0002-5459-2668 \\ Federal University of Lavras, Brazil \\ E-mail: marinarates@hotmail.com \\ Elesandra da Silva Araujo \\ ORCID: https://orcid.org/0000-0002-8295-1891 \\ Federal University of Lavras, Brazil \\ E-mail: elesandra.florestal@gmail.com \\ Mário Sérgio Lorenço \\ ORCID: https://orcid.org/0000-0002-1876-0994 \\ Federal University of Lavras, Brazil \\ E-mail: mslorenco@gmail.com \\ Fábio Akira Mori \\ ORCID: https://orcid.org/0000-0002-7468-018X \\ Federal University of Lavras, Brazil \\ E-mail: morif@ufla.br
}

\begin{abstract}
Tannins from Myrcia splendens from the Amazon rainforest were used for the first time in the formulation of a urea-tanninformaldehyde (UTF) resin. The objective was to evaluate the effect of different tannin proportions on the glue line performance in Pinus sp. woods, glued with UTF adhesive. The tannins were extracted in a water bath, using $1500 \mathrm{~mL}$ of water and $100 \mathrm{~g}$ of dry bark (liquor/bark 15:1), with addition of $3 \% \mathrm{Na}_{2} \mathrm{SO}_{3}$, at a temperature of $70{ }^{\circ} \mathrm{C}$ for three hours. The adhesives formulations were based on the gradual replacement of mass of the urea-formaldehyde (UF) adhesive by tannin powder, totalizing four compositions and one control treatment. UTF adhesives were evaluated for their physicochemical properties, shear bond strength (wet and dry) and wood failure. The addition of M. splendens tannins to the urea formaldehyde adhesive promoted an increase in glue line strength. The proportion of $5.0 \%$ of tannins proved to be ideal in the formulation of the UTF adhesive, considering all the parameters evaluated. Thus, this study proves the potential use of Amazonian tannins from Myrcia splendens in the partial composition of more sustainable UTF adhesives.
\end{abstract}

Keywords: Urea-tannin-formaldehyde; Copolymerized adhesives; Glue line; Amazonian vegetal tannins.

\section{Resumo}

Os taninos de Myrcia splendens da Floresta Tropical Amazônica foram usados pela primeira vez na formulação de uma resina de urea-taninos-formaldeído (UTF). O objetivo foi avaliar o efeito de diferentes proporções de taninos no desempenho da linha de colagem em madeiras de Pinus sp. coladas com adesivo UTF. Os taninos foram extraídos em banho-maria, utilizando 1500 $\mathrm{mL}$ de água e $100 \mathrm{~g}$ de casca seca (licor/escamas 15:1), com adição de $3 \%$ de $\mathrm{Na}_{2} \mathrm{SO}_{3}$, a uma temperatura de $70{ }^{\circ} \mathrm{C}$ durante três horas. As formulações dos adesivos foram baseadas na substituição gradual da massa do adesivo urea-formaldeído (UF) por pó de tanino, totalizando quatro composições e um tratamento de controle. Os adesivos UTF foram avaliados por suas propriedades físico-químicas, resistência ao cisalhamento (úmido e seco) e falha da madeira. A adição dos taninos de $M$. splendens ao adesivo de uréia formaldeído promoveu um aumento na resistência da linha de cola. A proporção de 5,0\% de taninos provou ser ideal na formulação do adesivo UTF, considerando todos os parâmetros avaliados. Assim, este estudo comprova o uso potencial dos taninos amazônicos de M. splendens na composição parcial de adesivos UTF mais sustentáveis. Palavras-chave: Urea-taninos-formaldeído; Adesivos copolimerizados; Linha de cola; Taninos vegetais amazônicos. 


\section{Resumen}

Los taninos de Myrcia splendens de la selva amazónica se utilizaron por primera vez en la formulación de una resina de ureatanino-formaldehído (UTF). El objetivo era evaluar el efecto de diferentes proporciones de taninos sobre el rendimiento de la línea de encolado en maderas de Pinus sp., encoladas con adhesivo UTF. Los taninos se extrajeron en un baño de agua, utilizando $1500 \mathrm{~mL}$ de agua y $100 \mathrm{~g}$ de corteza seca (licor/corteza 15:1), con adición de $3 \%$ de $\mathrm{Na}_{2} \mathrm{SO}_{3}$, a una temperatura de 70 ${ }^{\circ} \mathrm{C}$ durante tres horas. Las formulaciones de los adhesivos se basaron en la sustitución gradual de la masa del adhesivo de ureaformaldehído (UF) por polvo de tanino, totalizando cuatro composiciones y un tratamiento de control. Se evaluaron las propiedades fisicoquímicas de los adhesivos UF, la resistencia a la cizalladura (en húmedo y en seco) y el fallo de la madera. La adición de taninos de M. splendens al adhesivo de urea formaldehído promovió un aumento de la resistencia de la línea de pegado. La proporción del 5,0\% de taninos resultó ser ideal en la formulación del adhesivo UTF, teniendo en cuenta todos los parámetros evaluados. Por lo tanto, este estudio demuestra el uso potencial de los taninos de Myrcia splendens del Amazonas en la composición parcial de adhesivos UTF más sostenibles.

Palabras clave: Urea-tanino-formaldehído; Adhesivos copolimerizados; Línea de pegado; Taninos vegetales amazónicos.

\section{Introduction}

Wood-based panels are produced from the reconstitution of wood fibers, particles or veneers with formaldehydebased resins, under specific heat and pressure conditions. These products are targeted for non-structural and structural uses, such as furniture, common housewares, cabinets, frames, doors, floors, "I" beams, and trusses (Santos et al., 2020; Ang et al., 2019).

Despite the global economic slowdown scenario, the production of reconstituted wood panels was approximately 176.7 million $\mathrm{m}^{3}$ in 2019 , remaining relatively stable by decreasing only $0.2 \%$ from the previous year (Brazilian Tree Industry 2020). Associated with the high demand for wood panels is the expressive consumption of synthetic adhesive. The ureaformaldehyde (UF) resin is the most consumed and according to Dorieh et al. (2019) more than 80\% of the world's composite industries use UF in their products, due to the low cost compared to other synthetic resins and good adhesion properties.

However, commercial resins have some disadvantages related to price fluctuations, formaldehyde emission and environmental pollution (Shirmohammadli et al., 2018), this is because, when formulated, they depend on non-renewable petrochemical resources ( $\mathrm{Li}$ et al., 2020), as for the release of formaldehyde to the environment, it can occur during and after the production of wood panels (Ferreira et al., 2019). The post-production release is currently ranked as the main environmental problem associated with wood panel adhesives derived from fossil resources (Araujo et al., 2021), due to the high threat to human health. Constant inhalation of formaldehyde can cause damage to the respiratory and nervous system, eyes, and even lead to cancer and leukemia (Tang et al., 2011). These issues have encouraged the use of alternative chemicals to replace all or part of the petrochemical components of synthetic resins (Jia et al., 2020), especially if the change promotes reduced formaldehyde emissions and improves the adhesive's performance in this regard (Zhao et al., 2018).

In this context, tannins have shown high efficiency, for having a favorable chemical composition for the formulation of adhesives with low formaldehyde emission. Moreover, tannins gain prominence for being a renewable resource obtained from different parts of some trees, especially the bark. The ability of tannins to reduce formaldehyde emission, stems from the high reactivity with this volatile compound (Pizzi, 2008; Xi et al., 2019). Thus, when some percentages of tannins are added to synthetic resins in a process known as copolymerization it is known to occur to decrease formaldehyde emission (Shirmohammadli et al., 2018).

Tannins have high economic and ecological interest and can be used as raw material in the production of adhesive for wood bonding (Monteiro et al., 2006; Mendoza et al., 2017). They can be considered suitable for adhesive formulation when they have a Stiasny index value higher than 65\% (Yazaki and Collins, 1994), meaning a strong interaction of formaldehyde with condensed tannins. Among the forest species that produce condensed tannins, the species Myrcia splendens (Sw.) DC. of the Myrtaceae family, which occurs frequently in secondary forests of the Brazilian Amazon, has a high concentration of condensed tannins. According to Araujo (2019), 21.5 to $29.9 \%$ of condensed tannins can be found in the barks of the trunk of 
this species with a Stiasny index of $86.6 \%$, a value that allows its use in the production of adhesives. Thus, tannins from $M$. splendens were used for the first time in the formulation of a urea-tannin-formaldehyde (UTF) resin, with the objective of evaluating the effect of different tannin proportions on the glue line performance in Pinus sp. woods, glued with UTF adhesive.

\section{Material and Methods}

\subsection{Sampling}

The bark of M. splendens was collected from the trunk of 10 trees with a mean diameter of $10.9 \mathrm{~cm}$ and mean total height of $9.6 \mathrm{~m}$ in a secondary forest located in São João da Ponta, Pará, Brazil. The bark was air-dried and ground in a hammer mill. The wood used was extracted from an experimental plantation of Pinus sp. from the region of Lavras, Minas Gerais, Brazil, which were made into sheets $30 \mathrm{~cm}$ long, $10 \mathrm{~cm}$ wide and 0.5 thick.

\subsection{Tannins extraction}

The extraction of tannins from M. splendens barks was performed as presented in Araujo et al. (2021). Briefly, the barks were added in water at a 1:15 (w/v) ratio with the addition of $3 \%$ sodium sulfite $\left(\mathrm{Na}_{2} \mathrm{SO}_{3}\right)$ in relation to the dry mass. The extractions were performed in a water bath at $70^{\circ} \mathrm{C}$ for $3 \mathrm{~h}$ under periodic stirring. Once the extraction was finished, the material was filtered through a $1 \mathrm{~mm}^{2}$ mesh sieve. Subsequently, the extract was filtered using glass crucibles of porosity $\mathrm{n}^{\circ} 2$ in a vacuum system and dried in an oven at a temperature of $40^{\circ} \mathrm{C}$. Then, the tannins were macerated to a particle size of 200 mesh.

\subsection{Adhesive production and characterization}

The adhesive formulations were based on the gradual addition of powdered tannins to the urea-formaldehyde (UF) adhesive mass, totaling four compositions besides the control adhesive (Table 1).

Table 1. Different compositions of the adhesive Urea formaldehyde with powdered tannins.

\begin{tabular}{|c|c|c|}
\multirow{2}{*}{ Treatment } & \multicolumn{2}{c}{ Composition (\% mass) } \\
\cline { 2 - 3 } & Urea-formaldehyde adhesive & Powdered tannins \\
\hline UF-100 & 100 & 0 \\
\hline UF-97.5 & 97.5 & 2.5 \\
\hline UF-95.0 & 95.0 & 5.0 \\
\hline UF-92.5 & 92.5 & 7.5 \\
\hline UF-90.0 & 90.0 & 10 \\
\hline
\end{tabular}

Source: Authors.

For all adhesives produced their properties of solid content, $\mathrm{pH}$, gel time and viscosity were determined in triplicate. The solid content was determined according to ASTM-D 158260 (1994), the pH was obtained by direct readings in a pH meter, the gel time was performed by the methodology proposed by Almeida et al. (2010) and the viscosity was determined using a Ford Cup type viscometer following the parameters stipulated by ASTM D-1200 (1994).

\subsection{Assessment of glue line strength}

The Pinus sp. wood sheets used in the test had dimensions of $30 \times 10 \times 0.5$ (length $\mathrm{x}$ width $\mathrm{x}$ thickness) and approximately $8 \%$ humidity. For gluing the wood, $250 \mathrm{~g} \cdot \mathrm{m}^{-2}$ of adhesive was applied in a double glue line. A pressing cycle was used with a temperature of $140{ }^{\circ} \mathrm{C}$, a specific pressure of $8 \mathrm{kgf} \mathrm{cm}^{-2}$ and a pressing time of 8 minutes. After gluing, the 
slides were placed in an air-conditioned room with temperature conditions of $20 \pm 3{ }^{\circ} \mathrm{C}$ and humidity of $65 \pm 3 \%$. After the conditioning period, the glue line strength test was carried out following the recommendations of the American Society for Testing and Materials - ASTM D - 905 (ASTM, 2008). The effect of tannin addition on glue line strength was analyzed in dry and wet conditions after $24 \mathrm{~h}$ of immersion in water and each condition was evaluated with ten repetitions. Shear strength was calculated from the ratio of maximum load and shear area (Araujo et al., 2021).

\subsection{Evaluation of the failure rate on the glue line}

After shear testing, the samples were analyzed for glue line failure according to standard D5266-99 (ASTM, 2013). A checkered transparent sheet with its respective areas delineated in percentages was used, which was arranged over the sheared area and the percentage of failure in the wood was determined.

\subsection{Statistical analysis}

To evaluate the variations on the results of the adhesive properties according to the percentage of tannins added to the Urea formaldehyde resin, the data were submitted to analysis of variance (ANOVA) and, when significant differences were established for regression analysis. The Scott-Knott test was applied to verify the differences between the two conditions (wet and dry) of the shear bond strength test. The significance level of $5 \%(\alpha=0.05)$ was adopted for all statistical analyses. The analyses were performed in Sisvar 5.6 software (Ferreira, 2019). In addition, to clusters the samples according to the analyses performed, the hierarchical cluster analysis (HCA) was performed in the RStudio software version 1.4.1106.

\section{Results and Discussion}

\subsection{Adhesive properties}

The solids content (TS) is the fraction of the adhesive that polymerizes after pressing the wood. This property oscillated with high and low values depending on the tannin content, the polynomial regression (degree 4) was the one that best represented the relationship of solids with the different concentrations of tannins in the UF resin (Figure 1).

Figure 1. Average values of solids content of urea formaldehyde adhesive with different concentrations of M. splendens tannins.

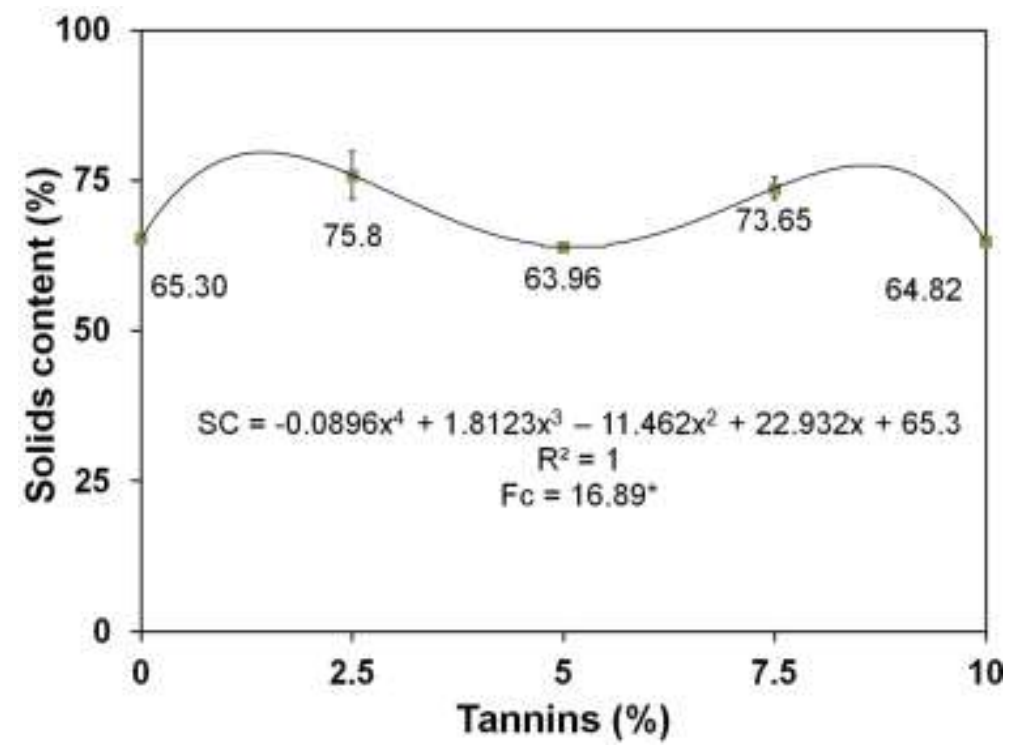

Source: Authors. 
Viscosity is an important parameter that shows the quality of the adhesive for wood bonding (Araujo et al., 2021). The adhesives with tannin addition showed values between 6000 and $8500 \mathrm{mPa}$.s. For satisfactory bonding, extreme values of viscosity are not desirable. When the adhesive viscosity is high, it is difficult to distribute the adhesive evenly over the wood, causing insufficient penetration into the wood structure, damaging the wetting, and possibly resulting in thick glue lines. However, adhesives with low viscosity have greater penetration and their absorption by the wood is also greater and may result in a hungry glue line (Iwakiri and Trianoski, 2020). The viscosity of tannin solution is generally higher than that of synthetic resins for the same concentration because it is influenced by the molecular weight of the tannins and the presence of non-tannic compounds such as gums and sugars (Pizzi, 2003), hence tannic extracts are more viscous at the concentrations typically required in adhesives compared to synthetic resins (Pizzi,1994). However, adhesive viscosity can be reduced by chemical modification of tannins, some studies recommend the methods of sulfitation and acid hydrolysis, in addition to the use of sodium hydroxide and urea (Carneiro et al., 2001; Vázquez et al., 2013; Solt et al., 2019).

The inclusion of tannins promoted a decrease in $\mathrm{pH}$ and gel time of the UTF adhesive (Figure 2AB). For each $1 \%$ of tannins added in the synthetic adhesive, a reduction of $0.0937 \mathrm{in} \mathrm{pH}$ and $1.1697 \mathrm{~min}$ in gel time was observed. $\mathrm{pH}$ in acidic ranges can influence the behavior of the gel phase, accelerating the curing of adhesives (Dunky, 2003). For this reason, in UF resins, usually to accelerate curing an acid-releasing catalyst, such as ammonium sulfate, is used. In tannic adhesives, the use of curing accelerators is not necessary, because polyphenols have an acidic character ( $\mathrm{pH}=4.0$ to 5.0) (Gonçalves and Lelis, 2009), which explains the decrease in polymerization time as tannins were added to the UF resin (Figure 2B). These results show that tannins, in addition to promoting sustainability and biosafety to the composition of the UF adhesive, can act as curing catalysts in the synthetic resin, reducing production costs.

Figure 2. Average $\mathrm{pH}$ values (A) and Gel Time (B) of the urea formaldehyde adhesive with different concentrations of $M$. splendens tannins.
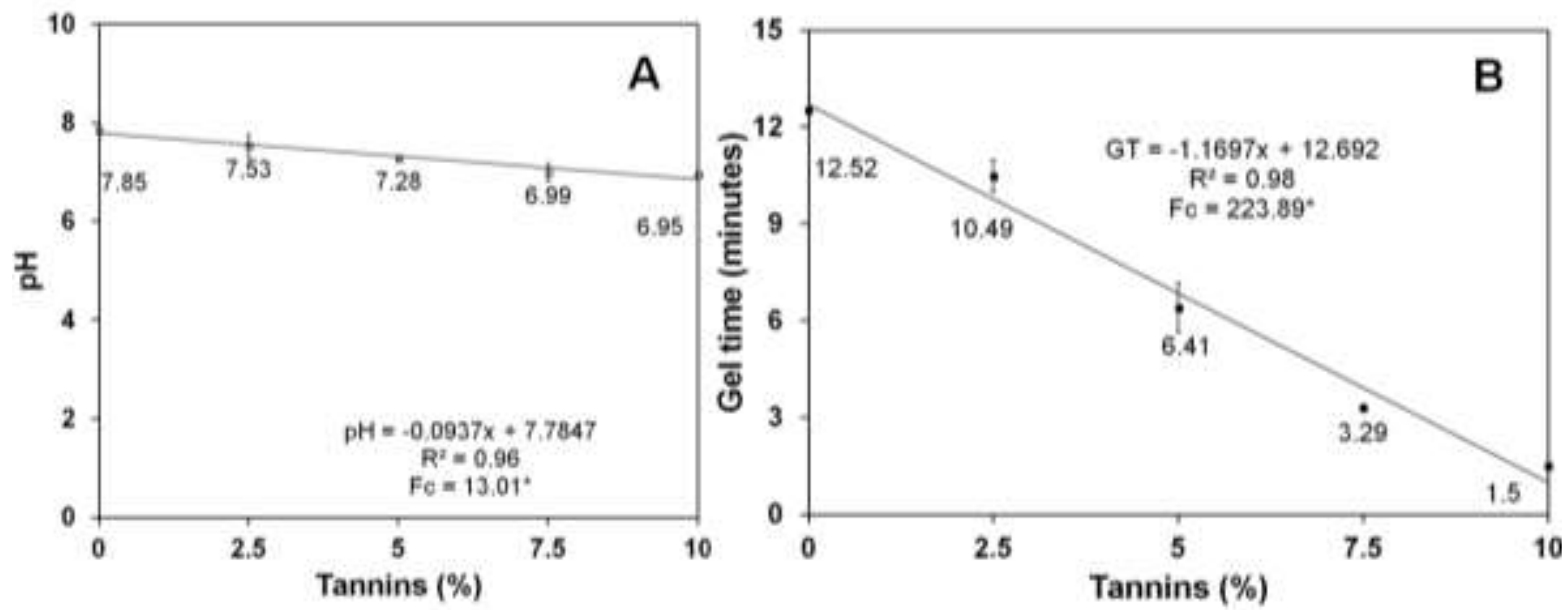

Source: Authors.

\subsection{Mechanical resistance of the glue line}

The adhesives prepared with replacement of UF by tannins were tested for shear bond strength in the dry and wet condition. The shear strength showed significant difference among the compositions evaluated (Figure 3). In the dry condition, the glue line strength reached 4.95 MPa with the inclusion of 10\% tannins (Figure 3A), representing a 52\% increase in this mechanical property. In the wet condition (Figure 3B), the adhesives with 5\% and 7.5\% of tannins were the ones that presented the best results, with 4.65 and $5.02 \mathrm{MPa}$, respectively. 
Figure 3. Mean values of shear strength at the glue line of the urea formaldehyde adhesive with different concentrations of $M$. splendens tannins in dry (A) and wet (B) test.
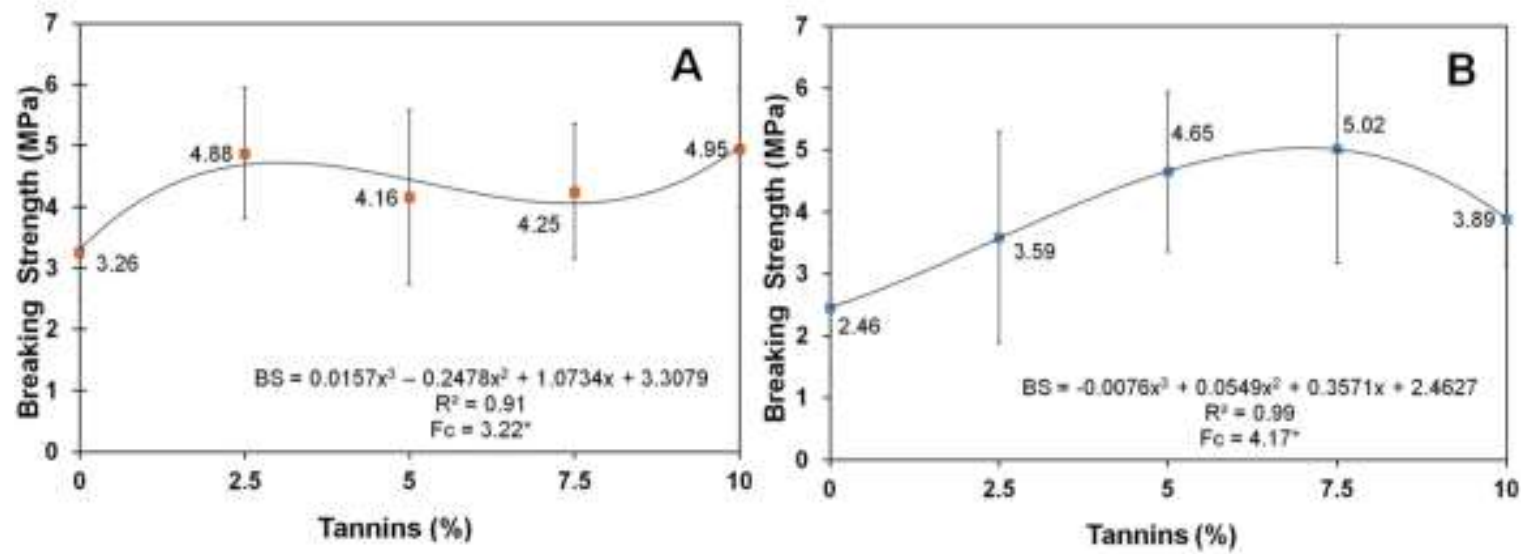

Source: Authors.

In both dry and wet conditions, the results were higher when compared to those described by Araujo et al. (2021) for the tannic adhesive of the species Myrcia eximia [5.3 and 4.2 MPa (dry and wet, respectively)], which belongs to the same botanical genus as the species in this study. The authors considered the values high and found that the thermal stability of these tannins in the face of high temperatures may have been responsible for the resistance, because the temperature of $140{ }^{\circ} \mathrm{C}$ used in the pressing did not promote the loss of mass of the tannins during bonding.

In relation to other tannin-rich species, UTF adhesives were even more resistant than tannic adhesives from Stryphnodendron astringens (2.24 MPa) and Acacia mearnsii (2.02 MPa) (Goulart et al., 2012). In addition, they had shear strength values close to those reported by Boa et al. (2014), who evaluated glued joints of Eucalyptus sp. wood with urea formaldehyde adhesive, in two density classes, which were, density below $0.65 \mathrm{~g} \mathrm{~cm}^{-3}(\mathrm{C} 1)$ and density above $\mathrm{g} \mathrm{cm}{ }^{-3}(\mathrm{C} 2)$ with a weight of urea formaldehyde adhesive of $200 \mathrm{~g} \mathrm{~m}^{-2}$ and obtained results of 4.09 to $8.36 \mathrm{MPa}$, respectively. When comparing the shear bond strength results according to the two test conditions (dry and wet), it can be observed that there was a statistical difference only with the $10 \%$ tannin content (Figure 4). This result shows that the addition of up to $7.5 \%$ tannins does not reduce the adhesives wet strength. In general, it is possible that the result obtained for moisture resistance is due to the chemistry of $M$. splendens species tannins, making them less hygroscopic when compared to tannins from other species. 
Figure 4. Evaluation of adhesive shear strength between dry and wet test condition.

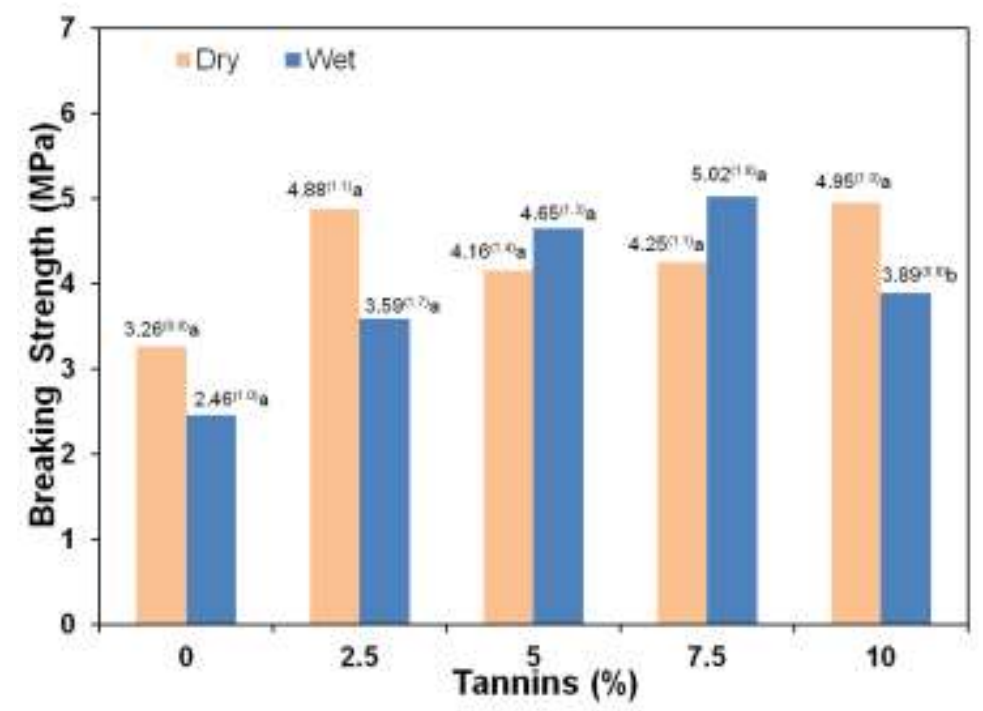

Source: Authors.

\subsection{Glue line failure ratio}

The gluing quality was also proven by the evaluation of the percentage of failure in the glue line after the shear tests. In the dry test condition, only $20.5 \%$ of the breaks occurred at the glue line (Table 2), in which, as tannins were added to the UF resin, the breaks in the wood increased, in other words, the UTF adhesive proved to be more resistant as tannins were added. In the humid condition, $73.2 \%$ of the breaks occurred in the glue line (Table 2), even so, these results are encouraging, since the urea formaldehyde resin is not resistant to humidity, therefore, it is indicated for bonding products for internal use with mild humidity conditions, and tannins promoted an increase in the resistance of the UF adhesive in both test conditions.

Table 2. Percentage of glue line failure after shear tests.

\begin{tabular}{|c|c|c|c|c|} 
& \multicolumn{4}{|c}{ Test Conditions } \\
\cline { 2 - 5 } Treatment & \multicolumn{3}{|c}{ Dry } & \multicolumn{2}{c}{ Wet } \\
\cline { 2 - 5 } & Wood & Glue line & Wood & Glue line \\
\hline UF-100 & 11.5 & 8.9 & 0.2 & 18.0 \\
\hline UF-97.5 & 13.3 & 4.9 & 8.0 & 14.7 \\
\hline UF-95.0 & 16.5 & 3.9 & 10.2 & 10.3 \\
\hline UF-92.5 & 18.2 & 2.3 & 1.1 & 17.1 \\
\hline UF-90.0 & 20.0 & 0.5 & 7.3 & 13.1 \\
\hline Total & 79.5 & 20.5 & 26.8 & 73.2 \\
\hline
\end{tabular}

Source: Authors.

\subsection{Hierarchical Cluster Analysis (HCA)}

Figure 5 shows the HCA analysis for the tests performed on the formulated adhesives. HCA is a statistical technique of grouping samples with similar characteristics. The treatments were grouped into 3 clusters, and we can see that the treatments UF-100 and UF-97.5 have distinct characteristics and are considered treatments with no similarities among themselves, neither with the other adhesives. Treatments UF-95, UF-92.5 and UF-90 formed a single cluster. Observing the intra-group diversities, the treatment with $7.5 \%$ tannin addition showed a small difference from the other treatments. In addition, the UF-90 and UF-95 treatments proved to be more similar to each other than the UF-92.5 adhesive. 
Figure 5. Dendogram obtained by the hierarchical cluster analysis.

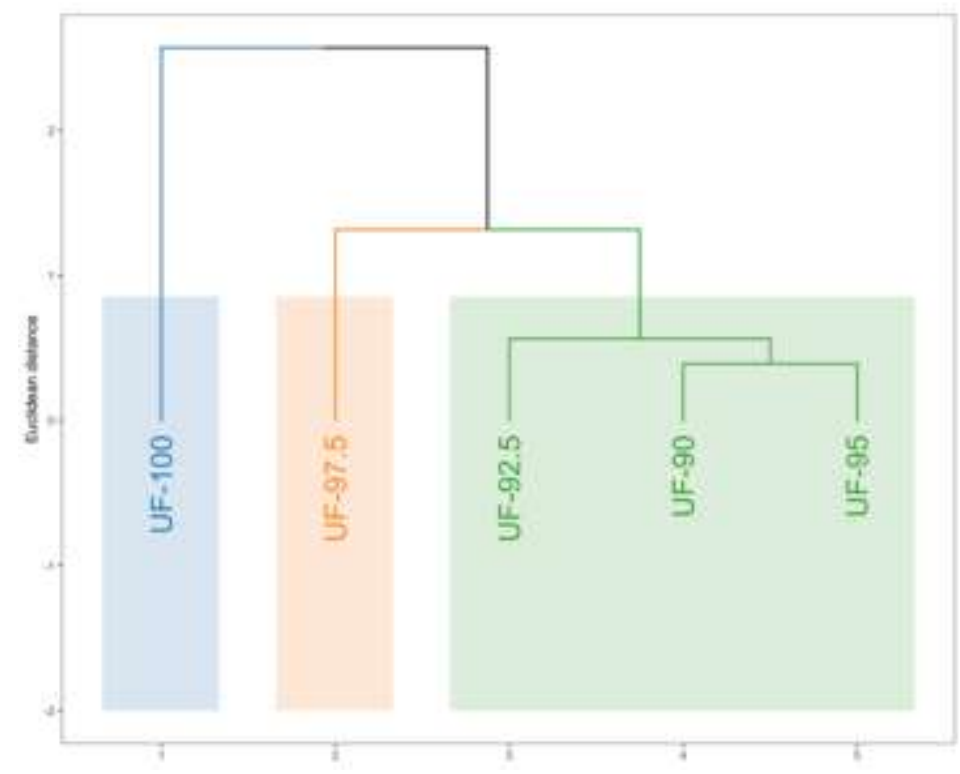

Source: Authors.

\section{Conclusion}

The $M$. splendens tannins added to the urea formaldehyde adhesive promoted, in general, an increase in the glue line strength, proving the quality of the urea-tannin-formaldehyde (UTF) adhesives, which were compatible with the commercial ones. Considering all parameters evaluated, the proportion of 5.0\% of tannins proved to be ideal in the formulation of the UTF adhesive, because in this mixture, besides not having significant difference in shear bond strength in dry and wet conditions, the percentage of failures were equivalent between the wood and the glue line in the wet test, as well as the gel time (6.41) was the closest to the pressing time. Thus, this study proves the potential use of Myrcia splendens tannins from the Amazon Rainforest in the partial formulation of more sustainable UTF adhesives, however, even more studies and improvements should be carried out to produce adhesives with better performance, especially aiming at reducing viscosity.

\section{Acknowledgements}

The authors would like to thank Minas Gerais Research Foundation (FAPEMIG), National Council for Scientific and Technological Development (CNPq) and Coordination for the Improvement of Higher Education Personnel (CAPES) (Funding Code 001) for supplying the equipment and financial support. We also thank the employees of the Herbarium of Embrapa Eastern Amazon (IAN) for the identification of the specie.

\section{References}

Almeida, N. F., Mori, F. A., Goulart, S. L., \& Mendes, L. M. (2010). Estudo da reatividade de taninos de folhas e cascas de barbatimão Stryphnodendron adstringens (Mart.) Coville. Science Forestaly, 38:401-408.

American Society for Testing and Materials. ASTM - D1582-60. (1994). Annual book of Standards. Denver.

American Society for Testing and Materials. ASTM D - 905. (2008). Standard Test Method for Strength Properties of Adhesive Bonds in Shear by Compression Loading. Philadelphia.

American Society for Testing and Materials. ASTM D-1200. (1994). Test Method for Viscosity by Ford Viscosity.

American Society for Testing and Materials. ASTM D-5266-13. (2013). Standard Practice for Estimating the Percentage of Wood Failure in Adhesive Bonded Joints. West Conshohocken, PA, 8p. 
Ang, A. F., Ashaari, Z., Lee, S. H., Tahir, P. M., \& Halis, R. (2019). Lignin-based copolymer adhesives for composite wood panels - A review. International Journal of Adhesion and Adhesives, 102408. https://doi.org/10.1016 / j.ijadhadh.2019.102408

Araujo, E. (2019). Caracterização das cascas de duas espécies florestais da Amazônia e a produção de adesivos naturais baseados em seus taninos. Dissertação (Mestrado em Ciências e Tecnologia da Madeira). Universidade Federal de Lavras, Lavras, 63p .

Araujo, E. S., Lorenço, M. S., Zidanes, U. L., Sousa, T. B., Mota, G. S., Reis, V. N. O., Silva,M. G., \& Mori, F. A. (2021). Quantification of the bark Myrcia eximia DC tannins from the Amazon rainforest and its application in the formulation of natural adhesives for wood. Journal cleaner production, 280 : 124324. https://doi.org/10.1016/j.jclepro.2020.124324.

Boa, A. C., Gonçalves, F. G., Oliveira, J. T. S., Paes, J. B., \& Arantes, M. D. (2014). Resíduos madeireiros de eucalipto colados com resina ureia formaldeído à temperatura ambiente. Scientia Forestalis, 42279-288.

Carneiro, C. O. A., Vital, R. B., Pimenta, S. A., \& Mori, A. F. (2001). Reatividade dos taninos da casca de Eucalyptus grandis para produção de adesivos. Cerne, 7: 1-9.

Dorieh, A., Mahmoodi, N. O., Mamaghani, M., Pizzi, A., Zeydi, M. M., \& Moslemi, A. (2019). New insight into the use of latent catalysts for the synthesis of urea formaldehyde adhesives and the mechanical properties of medium density fiberboards bonded with them. European Polymer Journal, 112: 195-205. https://doi.org/ 10.1016/j.eurpolymj.2019.01.002

Dunky, M.(2003). “Adhesives in the Wood Industry”, In: Pizzi, A., Mittal, K.L. (Org.). Handbook of adhesive technology, 2 ed., chapter 47, New York, Mareei Dekker.

Goulart, S. L., Mori, F. A., Almeida, N. F., Mendes, R. F., \& Mendes, L. M.(2012). Resistência ao cisalhamento de painéis compensados produzidos com adesivo à base de taninos de Stryphnodendron adstringens (barbatimão). Floresta e Ambiente, 19:308-315.

Ferreira, A. M., Pereira, J., Almeida, M., Ferra, J., Paiva, N., Martins, J., Magalhães, F. D., \& Carvalho, L.H. (2019). Low-cost natural binder for particle boards production: study of manufacture conditions and stability. International Journal of Adhesion and Adhesives, https://doi.org/10.1016/j.ijadhadh. 2019.01.019.

Ferreira, D. F. (2019). SISVAR: A computer analysis system to fixed effects split plot type designs. Rev. Bras. Biometria, 37: 529-535. https://doi.org/10.28951/rbb. v37i4.450.

Indústria brasileira de árvores - Ibá. (2020). Relatório Anual 2020.

Iwakiri, S., \& Trianoski, R. (2020). Painéis de madeira reconstituída. (2a ed.), Fundação de Pesquisas Florestais do Paraná, 259 p.

Jia, L., Chu, J., Li, J., Ren, J., Huang, P., \& Li, D.(2020). Formaldehyde and VOC emissions from plywood panels bonded with bio-oil phenolic resins. Environmental Pollution, 264: 114819. https://doi.org/10.1016/j.envpol.2020.114819

Li, D., Zhuang, B., Wang, X. A., Wu, Z.,Wei, W., Aladejana, J. T. Hou, X., Yves, K. G. Xie, Y., \& Liu, J.(2020). Chitosan used as a specific coupling agent to modify starch in preparation of adhesive film. Journal of Cleaner Production, 277: 123210. https://doi.org/10.1016/j.jclepro.2020.123210

Mendoza, Z. M. S. H., Borges, P. H. M., Ribeiro, A.S., \& Fernandes, F. B. (2017). Aspectos gerais sobre adesivos para madeira. Multitemas, 22:49-68. https://doi.org/10.20435/multi.v22i51.1412.

Monteiro, J. M., Albuquerque, U. P., Neto, E. M. F. L., Araújo, E. L., Albuquerque, M. M., \& Amorin, E. L. C. (2006).The effects of seasonal climate changes in the caatinga on tannin levels in Myracrodruon urundeuva (Engl.) Fr. All. and Anadenanthera colubrina (Vell.) Brenan. Revista Brasileira de Farmacognosia,16: 338-344.

Pizzi, A. (1994). Advanced wood adhesives technology. Marcel Dekker.

Pizzi, A. (2003). "Natural phenolic adhesives I: Tannin”. In: Pizzi, A., Mittal, K.L. (Org.), Handbook of adhe-sive technology, (2a ed.), chapter 27, Marcel Dekker, pp. 347-358.

Pizzi, A. (2008). Tannins: major sources, properties and applications. In: Belgacem, M.N., Gandini, A. (Eds.), Monomers, Polymers and Composites from Renewable Sources. Elsevier, 179-199.

Shirmohammadli, Y., Efhamisisi, D., \& Pizzi, A. (2018). Tannins as a sustainable raw material for green chemistry: A review. Industrial Crops and Products, 126: 316-332. https://doi.org/10.1016/j.indcrop.2018.10.034

Santos, P., Pitarch, J, L., Vicente, A., Prada, C., \& García, Á. (2020). Improving operation in an industrial MDF flash dryer through physics-based NMPC. Control Engineering Practice, 94:104213-. https://doi.org/10.1016/j.conengprac.2019.104213

Solt, P., Konnerth, J., Gindl-Altmutter, W., Kantner, W., Moser, J., Mitter, R., \& Herwijnen, H. W. G. V. (2019). Technological performance of formaldehyde-free adhesive alternatives forparticleboard industry. International Journal of Adhesion and Adhesives, 94:99-131.

Tang, L., Zhang, Z. G., Qi, J., Zhao,J. R., \& Feng, Y. (2011) .The preparation and application of a new formaldehyde-free adhesive for plywood. International Journal of Adhesion \& Adhesives, 31: 507-512.

Vázquez, G., Pizzi, A., Freire, M. S., Santos, J., Antorrena, G., \& González-Álvarez, J.(2013). MALDI-TOF, HPLC-ESI-TOF and 13C-NMR characterization of chestnut (Castanea sativa) shell tannins for wood adhesives. Wood Science and Technology, 47: 523-535. https://doi.org/10.1007/s00226-012-0513-8

Yazaki, Y., \& Collins, P. J. (1994). "Wood adhesives based on tannin extracts from barks of some pine and spruce species,” Holz Roh Werkst, 52: 307-310. https://doi.org/10.1007/BF02621420 
Research, Society and Development, v. 10, n. 12, e370101220543, 2021

(CC BY 4.0) | ISSN 2525-3409 | DOI: http://dx.doi.org/10.33448/rsd-v10i12.20543

Xi, X., Pizzi, A., Frihart, C. R., Lorenz, L., \& Gerardin, C. (2019). Bioadesivos de compensado de tanino com geração de aldeídos não voláteis por oxidação específica de mono- e dissacarídeos. International Journal of Adhesion and Adhesives, (), 102499-. https://doi.org/ 10.1016/ j.ijadhadh.2019.102499

Zhao, X-f., Peng, L-q., Wang, H-1., Wang, Y-b., \& Zhang, H. (2018). Environment-friendly urea-oxidized starch adhesive with zero formaldehyde-emission. Carbohydrate Polymers, 181: 1112-1118.https://doi.org/10.1016/j.carbpol.2017.11.035 